\title{
ОСОБЛИВОСТІ РОЗВИТКУ СПАДКОВОГО ДОГОВОРУ ТА ВПЛИВ ІНОЗЕМНОГО ЗАКОНОДАВСТВА НА ЙОГО ФОРМУВАННЯ
}

Кравчик М. Б.

Стаття присвячена дослідженню правової категорії спадкового договору. Проведено дослідження історичного розвитку спадкового договору, узагальнено законодавчі положення та проведено аналіз поглядів науковців з питань становлення і розвитку спадкового договору.

Розглянуто особливості у підходах до розуміння юридичної сутності спадкового договору та значення права країн континентальної системи права на розвиток і застосування цієї правової категорії.

Ключові слова: спадкування, спадкові правовідносини, спадкодавець, спадкоємець, спадковий договір.

Статья посвящена исследованию правовой категории наследственного договора. Проведено исследование исторического развития наследственного договора, обобщено законодательные положения и проведен анализ взглядов ученых по вопросам становления и развития наследственного договора.

Рассмотрены особенности в подходах к пониманию юридической сущности наследственного договора и значение права стран континентальной системы права на развитие и применение этой правовой категории.

Ключевые слова: наследование, наследственные правоотношения, наследодатель, наследник, наследственный договор.

The article is devoted to the study of the legal category of hereditary contract. The study of the historical development of the hereditary contract, the establishment of the institution of the hereditary contract, the influence of foreign law on the formation of the hereditary contract and its consolidation in domestic civil law, the study clarifies the legal nature of the treaty, as the views of scholars differ on its legal nature and place in the civil law system. Today, due to the ambiguous approach to understanding the essence of the hereditary contract, this transaction has not yet been fully recognized by the population and is not frequently used.

Generalization of doctrinal positions on the regulation of relations resulting from its conclusion and implementation also generalized the legislative provisions and analyzed the views of scientists on the formation and development of a succession agreement. The peculiarities in approaches to understanding the legal nature of the hereditary agreement and the importance of the right of the countries of the continental system of the right to development and application of this legal category are considered.

The purpose of the article is to investigate the formation of an institution of an inheritance agreement, the influence of foreign legislation on the formation of an inheritance agreement and its consolidation in domestic civil law, the generalization of doctrinal positions on the regulation of relations resulting from its conclusion and implementation.

Key words: inheritance, inherited legal relationships, to the inheritance between and adopted, heir, inherited agreement.

Постановка проблеми та іï актуальність. Сучасне цивільне законодавство дає право громадянам мати у власності будь-яке майно за винятком окремих об'єк- тів, які відповідно до національного законодавства не можуть їм належати. Однією з підстав виникнення права власності $\epsilon$ спадкування, гарантоване Конституцією України та цивільним законодавством.

Розвиток ринкових відносин в країні, зростання доходів населення, які викликали зростання кількості об'єктів цивільного обігу, в тому числі нерухомого майна, переважно зумовили і збільшення кількості угод, і зростання кількості спадкових справ, оскільки за відсутності спадкового майна немає необхідності вступати в право спадкування. Майно може перейти до іншої особи після смерті власника як наслідок спадкування за законом або за заповітом і на підставі спадкового договору.

Аналіз останніх досліджень і публікацій. Численні дослідження спадкового договору здійснювалися вітчизняними цивілістами та зарубіжними науковцями з цивільного та сімейного права, зокрема у працях 3.В. Ромовської, С.Я. Фурси, Є.І. Фурси, В.В. Васильченко, Ю.О. Заїки, Р.А Майданика, Д.С. Кучеренко, С.В. Мазуренко та інших. Питанню загальної характеристики спадкового договору та окремим його аспектам присвячені роботи Й.К. Гассе, В. Фогеля, Г. Отте, Г. Безелера та інших. Проте, незважаючи на наявність значної кількості наукових доробків, ця проблематика залишається актуальною, зважаючи на неоднозначність правової природи спадкового договору.

Виклад основного матеріалу. Спадковий договір пройшов довгий і складний історичний шлях свого становлення та розвитку. Насамперед, завдячуючи стародавньому римському праву, в якому містилися перші згадки про спадковий договір, згодом німецькому національному праву, завдяки якому спадковий договір можна вважати самостійним інститутом. Інститут спадкового договору має тісний зв'язок із підгалуззю зобов'язального, а не спадкового права, оскільки $є$ різновидом договорів про передачу майна у власність.

Найбільшу полеміку в українській юридичній літературі викликає 3'ясування правової природи цього договору, оскільки думки науковців розходяться стосовно його правової природи та місця в системі цивільного права. Натепер через неоднозначний підхід до розуміння сутності спадкового договору цей правочин ще не отримав визнання серед населення та не має частого застосування.

Метою статті $\epsilon$ дослідження становлення інституту спадкового договору, вплив іноземного законодавства на формування спадкового договору та його закріплення у вітчизняному цивільному праві, узагальнення доктринальних позицій щодо врегулювання відносин, які виникають у результаті його укладення та виконання. 
Виклад основного матеріалу. Спадкування є одним із найдавніших правових інститутів. 3 процесом вдосконалення цивільного законодавства постала низка теоретичних і практичних завдань у сприянні врегулюванню суспільних відносин шляхом зміцнення та охорони прав та інтересів його суб'єктів. Особливе місце в розвитку цивільного законодавства відведено спадковому праву. Важливе місце займає і спадковий договір, який сприяє забезпеченню гідного рівня життя особі та захисту її особистих майнових і немайнових прав.

Перші згадки про спадкування на українських землях з’являються у письмових джерелах княжої доби IX XII століть. Серед них важливе місце посідають церковні та княжі устави (установи), уроки, договір між греками і Руссю (874 рік), збірник права «Руська Правда». За безпосередньої участі Ярослава Мудрого була створена перша збірка правничих актів, яка отримала назву «Руська Правда»[3, с. 345]. До спадщини за «Руською Правдою» можна віднести: рухомі речі, будинок, подвір'я, товар, худобу. Землі не входили до складу спадщини, оскільки не були приватною власністю.

Перші згадки про спадковий договір з'явилися за часів розвитку римського права у європейські правовій системі. Тому у римському приватному праві існували лише дві підстави для відкриття спадщини: за заповітом або за законом. Варто зазначити, що римське право не допускало укладення спадкового договору, оскільки будь-які договори, що обмежували волю заповідача, в тому числі договори про відмову від спадщини, яка повинна була відкритися, вважалися недійсними. Існував лише один вид договору - це дарування на випадок смерті, але оскільки цей договір міг бути у будьякий час скасований, то він не вважався обов'язковим. Таке ж правило стосувалося договорів щодо відмови від права спадкування. Тому можна зробити висновок, що визнання ці договори в римському праві не знайшли, оскільки їх застосування могло стати причиною вбивства для отримання спадщини.

Спадкування за заповітом не відрізнялося від спадкування за законом. У заповіті можливе було призначення спадкоємцями тільки тих осіб, які б і так вступили у спадкування [4, с. 28]. Заповіт складався для того, щоб розподілити майно між спадкоємцями, а не змінити порядок спадкування, зокрема заповіт укладався в усній формі. У разі смерті спадкодавця без заповіту право на спадкування мали всі члени родини.

У «Руській Правді» першочергове право на спадкування мали сини, дочки мали право на спадок лише у випадку відсутності синів через патріархальний порядок їхнього життя. Частки спадку були рівними, за винятком частки молодшого сина, який успадковував будинок із подвір'ям, оскільки існувала думка, що старші брати до цього часу вже мали власне господарство.

Наступним законодавчим актом, який врегульовував спадкове право, була Псковська Судна Грамота, яка розрізняла спадкування за законом і за заповітом, викладеним у письмовій формі. Ці види спадкування набули самостійного значення. Розширилося і коло родичів, які могли бути спадкоємцями, змінилися їхні права та відповідальність [4, с. 28].

Наступним етапом розвитку спадкового права України був період Литовського князювання. Протягом майже 240 років переважна частина українських земель входила до складу Великого Литовського князівства
(1320-1560 роки). На зміну «Руській Правді» Ярослава Мудрого прийшли Литовські статути (видавалися у трьох редакціях 1529, 1566, 1588 років). Особливе місце статутом було виділено спадкуванню за заповітом (тестаментом), якому присвячено дев'ять артикулів. Право на укладення заповіту було надано шляхетним персонам, а також у певних межах - міщанам і простим людям, які на час вчинення заповіту мали бути у стані «доброї пам'яті і здоровому розумі». Не мали права вчиняти заповіти неповнолітні діти, челядь (дворова), полонені, особи з вадами розуму (шалені) та позбавлені честі. Особа, яка укладала заповіт, мала право в будь-який час скасувати його і вчинити новий. Статут визначав умови та порядок вчинення заповіту, зокрема щодо його вчинення під час перебування на війні, в дорозі, на «чужій землі».

У Московський період (XV ст.) важливості набула нерухомість, тому іï спадкуванню законодавець приділяв найбільшу увагу. Поступово розширилося коло спадкоємців, спадкувати мали право не тільки близькі, а й далекі родичі. За часів правління Петра I спадкове право зазнало дуже істотних змін. Відповідним указом 1714 року було встановлено перехід спадщини до одного сина. Імператор вважав розподіл спадкового майна дуже шкідливим, бо роздріб маєтків зменшував їхню економічну цінність та обтяжує селян, внаслідок чого страждало правильне надходження податей, знатні роди бідніли і втрачали свою значущість, а спадкоємці ухилялися від державної служби [3, с. 171]. Цим указом було покладено край спадкуванню за заповітом, яке вже мало значне поширення, тому цей акт зустрів протидію суспільства, що призвело до скасування указу в 1731 році.

Аналізуючи російську дореволюційну систему, можна зробити висновок, що спадкування було побудовано на принципах родового дворянського ладу, який на початку XX ст. вже застарів, що об'єктивно викликало необхідність перегляду основних засад спадкування. Проект Цивільного Уложення Російської імперії, який було створено за прикладом новітніх європейських кодифікацій, поділяв спадкоємців за законом на п'ять черг [5, с. 35]. Це був перший законодавчий акт, який затвердив розширення кола спадкоємців аж до прадідів спадкодавця. Подальші сторінки історії висвітлюють, що в інституті спадкування відбувалися підйоми й падіння.

Спадкове право із внесеними до нього у 1945 році змінами діяло без будь-яких істотних доповнень або вилучень аж до прийняття Верховною Радою СРСР «Основ цивільного законодавства Союзу РСР і союзних республік» від 1962 року. Основні принципові положення спадкового права, закріплені у ст. ст. 117-121 Основ, були конкретизовані у низках цивільних кодексів союзних республік, зокрема у ЦК УРСР від 18 липня 1963 року. Подальшого розвитку спадкове право України набуло в Цивільному кодексі УРСР 1963 року, де цьому інститутові було присвячено окремий розділ. Особливістю того часу було те, що спадкування за законом визнавалося первинним, а спадкування за заповітом - додатковим, тому цей спосіб не дуже поширився й не був ґрунтовно розроблений із правового погляду [4, с. 34].

В Україні спадковий договір був вперше закріплений уЦивільномукодексіУкраїни2003року (ст.ст. 1302-1308), а виник і розвивався в рамках німецького права. Найбільшу полеміку в українській юридичній літературі 
викликає з'ясування правової природи вказаного договору, оскільки думки науковців розходяться стосовно його правової природи та місця в системі цивільного права. На сьогодні через неоднозначний підхід до розуміння суті спадкового договору цей правочин ще не повністю отримав визнання серед населення та не має частого застосування.

Проте спадковий договір не може розглядатися як самостійний вид спадкування, оскільки відповідно до ст. 1217 ЦК України спадкування здійснюється за заповітом або за законом. У зв'язку з цим Пленум Верховного Суду України вказав, що перехід майна від відчужувача до набувача на підставі спадкового договору не $є$ окремим видом спадкування, а тому на відносини сторін не поширюються відповідні правила про спадкування, в тому числі право на обов'язкову частку. Тому розміщення глави 90 у книзі 6 цК України $є$ досить умовним. До спадкового договору не застосовуються норми спадкового права через відсутність юридичного складу спадкового правонаступництва [6, с. 104].

Важливу роль для розвитку спадкового договору відіграло і європейське законодавство. Договори про спадкування входять у систему права ФРН, Франції, Великої Британії та інших держав. У Цивільному уложенні Німеччини (параграфи 2274-2302) спадковий договір розглядається як окремий самостійний вид спадкування [2].

Можна беззаперечно дотримуватися думки, що спадковий договір $є$ здобутком німецького національного права, в межах якого він виник та отримав свій подальший розвиток і утвердження. Варто зазначити, що спадкові договори в Німеччині були відомі ще до поширення римського приватного права, але набули вагомого значення лише $з$ його рецепцією.

Вагомий внесок у розвиток спадкового договору здійснили німецькі вчені Штобб у теорії майнового характеру наступництва за договором, Гассе і Безелера у теорії спадкового наступництва за договором, які знайшли своє відображення в концепції Німецького цивільного уложення 1900 року (далі - НЦУ), яке регулювало порядок застосування норм договору щодо спадкування. Вчені виділяли дві основні групи спадкових договорів: позитивні (щодо спадкування в буквальному розумінні) і негативні (щодо відмови від права спадкування). Позитивними вважаються договори, за якими спадкодавець надає право на спадок спадкоємцю за договором. Негативними - у яких спадкоємець відмовляється від права спадкування за законом або ж від обов'язкової частки.

Відповідно до Німецького цивільного уложення (параграф 1941) спадковим договором $€$ правочин на випадок смерті, в якому обидві сторони договору або лише одна сторона, але з силою договірного зобов'язання приймають розпорядження щодо спадщини. Слід розуміти заповідальне розпорядження на випадок смерті з договірним характером, а не договір, з якого виникають зобов'язання (параграф 320 Німецького цивільного уложення) [7, с. 2]. Тобто, у німецькому праві спадковий договір слід розглядати як правочин, що укладається на підставі волевиявлення двох сторін, воля яких погоджена двома сторонами. До здійснення волевиявлення застосовуються норми загальної частини Німецького цивільного уложення та загальної частини зобов'язального права [8, с. 4]. Отже, в цьому випадку чітко прослідковується подвійна правова природа інституту спадкового договору.

Французьке цивільне законодавство, як зазначає Р.А. Майданик, негативно ставиться до спадкових договорів, проте допускає їх укладення лише між подружжям.

В англійському приватному праві укладення спадкового договору не передбачено, але допускається його існування. Тут передбачено договір, який укладається у випадку страждання особи на невиліковну смертельну хворобу, за яким ця особа може подарувати належне їй на праві власності майно, очікуючи смерті від смертельної хвороби. Проте обдаровуваний набуде подароване майно лише у випадку смерті дарувальника від цієї хвороби, а за дарувальником залишається право в будьякий час скасувати відповідний договір [9, с. 397].

Натепер спадковий договір міститься у Главі 90 цк України, проте його застосування відбувалося ще до цього часу із поширенням у 1811 році дії положень ЦК Австрії на території західноукраїнських земель, які перебували у складі Австрійської монархії аж до 1933 року, коли почав діяти польський кодекс зобов'язань. Відповідно до законодавства, яке діяло у цей період, однією з підстав спадкування поряд із заповітом і законом був спадковий договір, але за умови укладення його між подружжям.

Висновки. На основі наведеного вище можна зазначити, що інститут спадкового договору проходить тривалий процес становлення та відіграє важливу роль як інструмент регулювання відносин спадкування, що ґрунтується на праві власника вільно розпорядитися своїм майном на випадок смерті. Натепер правове регулювання інституту спадкового договору в Україні значно відрізняється від його правового регулювання у минулому. В сучасному правовому регулюванні інституту спадкового договору жодне положення з минулого не знайшло свого прояву.

Загалом спадковий договір пройшов довгий та складний історичний шлях свого становлення та розвитку, завдячуючи стародавньому римському праву, в якому містилися перші згадки про спадковий договір, згодом німецькому національному праву, завдяки якому спадковий договір можна вважати самостійним інститутом. Із прийняттям Конституції України 28 червня 1996 року відбулася переорієнтація суспільних відносин в Україні на охорону і захист прав громадян, побудову демократичної, правової держави, що зумовлює необхідність реформування й оновлення законодавства України, в тому числі і спадкового.

Досвід зарубіжних країн свідчить про те, що детальне регламентування умов у спадковому договорі, а також питань їх укладення, зміни й розірвання дає змогу ефективно використовувати його в цивільному обігу. Право держав континентальної системи права, а особливо Німеччини, мають велике значення для врегулювання та уточнення неоднозначних питань, які виникають з приводу укладення та застосування інституту спадкового договору серед вітчизняних науковців. Важливо, щоб було достатнє законодавче поле для забезпечення прав та обов'язків сторін спадкового договору. Необхідно використовувати позитивний досвід зарубіжних країн у цьому питанні для уникнення прогалин у вітчизняному законодавстві щодо регулювання відносин, які виникають на підставі укладення спадкового договору. 


\section{та господарського права}

\section{Література}

1. Цивільний кодекс України від 16 січня 2003 року № 435-IV. URL: http://zakon3.rada.gov.ua/laws/ show/435-15/page5.

2. Гражданское уложение Германии : Вводный закон к Гражданскому уложению: пер. с нем. / Науч. ред. А.Л. Маковский и др. 2-е изд., доп., науч. М. : Вольтерс Клувер, 2006. 583 с.

3. Кондратова А.М. Історія становлення i розвитку законодавства про спадкування в Україні / А.М. Кондратова // Часопис Київського університету права. К., 2014. № 3. С. 169-174.

4. Благовісний С.Г. Історичні аспекти інституту спадкового права України / С.Г. Благовісний // Часопис Київського університету права. К., 2006. № 2. С. 21-39.

5. Заїка Ю.О. Спадкове право: становлення і розвиток : моногр.; 2-е вид. / Ю.О. Заїка. К. : КТН, 2007. 285 с.

6. Кухарєв О. Спадкове право України : навч. посіб. / Кухарєв О. К. : Правова єдність, 2011. 224 С.
7. Soergel W. Manfred : Kommentar zum Bürgerlichen Gesetzbuch / Vor \$2274 BGB. Bd. 23, Erbrecht 3, Stuttgart 2002.

8. Löhnig M. Erbrecht, 2 Aufl., München, 2010.

9. Мазуренко С.В. Спадковий договір у цивільному праві України : дис. ... канд. юрид. наук: 12.00 .03 / Одеська національна юридична академія. О., 2004. [Електронний ресурс]. - Режим доступу: http://studrada.com.ua/ content/мазуренко-св-спадковий-договір-у-цивільному-праві-2004.

10. Спадкове право : навч. посіб. // Ю.О. Заїка, Є.О. Рябоконь. К. : Юрінком Інтер, 2009. 195 с.

Кравчик М. Б., кандидат юридичних наук, асистент кафедри цивільного права та процесу Львівського національного університету імені Івана Франка 